\title{
Management training as a senior/specialist registrar
}

\author{
M. F. Bowden
}

A placement involving management training is described and discussed in relation to the current specialist training requirements. The placement was unusual in that it included some practical involvement which was extremely rewarding.

The specialist training requirements (Royal College of Psychiatrists, 1995) specify the following as educational goals of higher training in management:

(a) Basic competence in time management.

(b) Adequate knowledge of trends in management and implications of management structures within the health service.

(c) Ability to develop new services and training through involvement in the setting and monitoring of contracts and advising purchasers. Experiences in personnel issues, group management, service planning and shadowing a manager are recommended.

I have been lucky enough to have had the opportunity to explore these objectives in depth during a placement which offered management experience to specialist registrars.

The experience was for one session a fortnight over one year and involved shadowing the medical director and other directors, attending management meetings, meetings with purchasers and fund-holders and receiving copies of management documentation 'as it happened' day-to-day. I attended a generic management course and had some direct teaching from the directors and visiting speakers.

I struggled with the training objectives in the training requirements. Why was time management the key personal skill identified? The second objective seemed immense and unfocused for a beginner such as myself. What was the crux of what I needed to learn? To tackle this, and because I felt unstructured 'sitting in on activities could be too passive a way of learning, I developed some formal learning objectives: attitude, skills and knowledge (see Table 1).
My experience was particularly valuable because I was lucky enough to observe management in a small, flexible trust where the management was largely effective. The trust gave high priority to mental health and had open and flexible boundaries. At times there were worries about confidentiality and at some meetings, notably the trust board, certain people would request my exclusion from certain items. However, most of the time my non-threatening role as a trainee, to an extent from outside the service. allowed people to be extremely open towards me. Attending the same meetings over a prolonged period allowed me to feel involved in the real issues for the trust.

Observation was no substitute for being involved, and I did not really grasp what developing and contracting services were about by attending purchasing meetings. I was fortunate to have the opportunity to participate in 'real' management by writing a business plan for the trust and I helped present it to the purchasers. This was my most valuable experience of the year. I experienced the pressure of management deadlines and of dealing with conflicts between clinicians. I experienced the frustration of wanting to develop a model that was good enough for service users and of having to make it sound attractive to managers' and purchasers' agendas, and having to make it cheap, so that the plan would be viable. By then I had some idea of what management could do for me (and the service) and a more realistic idea of the difficulties.

When confronted with this complexity, initially I felt ill prepared. Management training had previously seemed 'something for the $\mathrm{CV}$ ' and seemed divorced from my role as a clinician. Medical training in many ways teaches us to look for the convergent solution, 'the diagnoses', and gives us experience in hierarchical structures with fairly simple power relationships. This was a different place. I began to be thankful that psychiatrists are better prepared for management than many other specialities our experience of persuasion, communication, managing conflict, group dynamics, systems theory, team working etc. (British Association 


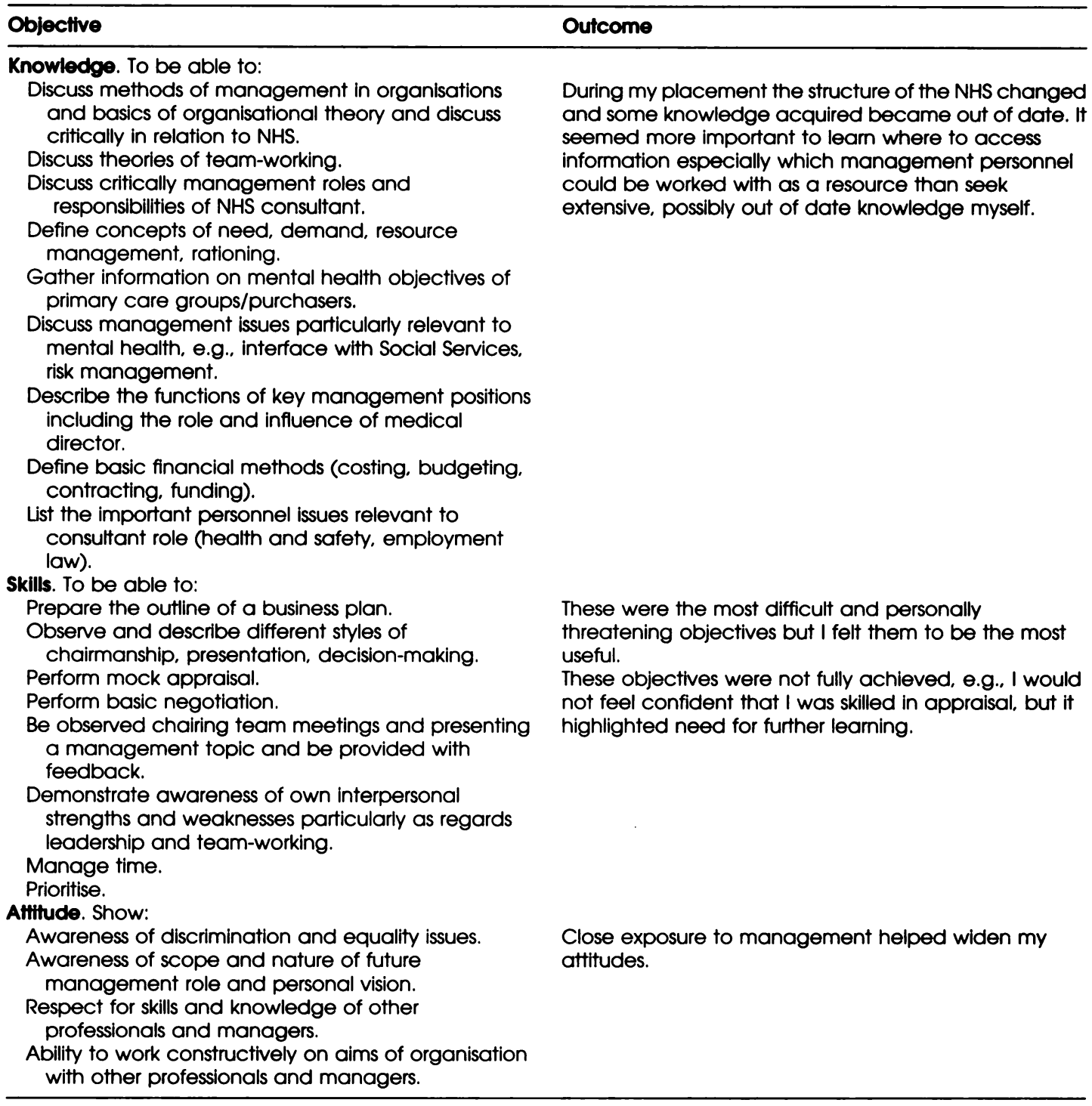

of Psychotherapists, 1989). At various times I was told by psychiatrists that management was like group therapy, family therapy (between purchasers and trust), parenting, manipulation, power and creativity. As I slowly realised how essential clinicians are to the management team for knowledge of the day-to-day issues and our proximity to the service users' needs, I also became grateful for the skills and perspective of managers. Interestingly, when I discussed the specialist training requirements with managers they felt they were not the things they saw as a priority. Rather, they were interested in educat- ing doctors on the management process, the management perspective and gave high priority to health and safety issues and legal issues concerned with personnel.

\section{Acknowledgements}

I thank Dr Stephen Logsdail and the management team at Aylesbury Vale Community NHS Trust. 


\section{References}

BHUGRA, D. \& BURNS, A. (1995) Management for Psychiatrists. London: Gaskell.

BRTISH ASSOCIATION OF PSYCHOTHERAPISTS (1989) The application of psychodynamic understanding to organizations in the helping services. London: British Association of Psychotherapists.

REDER, P. (1996) A management course for senior registrars. Psychiatric Bulletin, 20, 295-297.
ROYAl COLlEge OF PSYCHIATRISTS JOINT COMMTTEE ON HigheR PSYCHIATRIC TRAINING (1995) The Specialist Training Requirements. London: Royal College of Psychiatrists.

M. F. Bowden, Senior Registrar in Psychotherapy and Psychiatry, Winterbourne House, 53/55 Argyle Road, Reading RG1 TYL

\section{I999 Annual General Meeting}

\section{June - 2 July 1999}

\section{Working together towards the Millennium: a vision of a shared future.}

This year's meeting will be the first in which the college has concentrated its energies into a single Annual Meeting. The programme has been developed by a truly inter-faculty organising committee and, as a result, this flagship meeting will embrace the whole College community. Every discipline and specialty is represented in the programme, and it is our hope that all members of the College will be able to benefit from sessions which are relevant to their interests and clinical practice and form opportunities for interdisciplinary discussion.

27th May: Deadline for conference cancellation at low penalty and deadline for guaranteed accommodation. After this date hotel bookings will be wait-listed and placed as availability occurs by the Birmingham International Convention Centre.

28th May: Registration and full payment due for conference and social programme.

AGMVenue:The Birmingham International Convention Centre, Broad Street, Birmingham, tel: $+44(0) 1216446011$, fax: $+44(0) 1216433280$

Accommodation: To arrange accommodation please contact the Birmingham Convention and Visitor Bureau, tel: $+44(0) 1216656116$, fax: $+44(0) 1216433280$

All correspondence to: The Conference Office, The Royal College of Psychiatrists, 17 Belgrave Square, London, SWIX 8PG tel: +44 (0)171 2352351 , fax: +44(0)171 2596507 